\title{
Identification of Vegetation Change of Lower U Minh National Park of Vietnam from 1975 to 2015
}

\author{
P.T. Khanh ${ }^{1}$ and S.M.C.U.P. Subasinghe ${ }^{2 *}$ \\ ${ }^{1}$ Department of Environment, University of An Giang, Long Xuyen city, Vietnam. ${ }^{2}$ Centre for \\ Forestry and Environment, Department of Forestry and Environmental Science, University of \\ Sri Jayewardenepura, Nugegoda, Sri Lanka.
}

Date Received: 20-09-2017 Date Accepted: 10-12-2017

\begin{abstract}
The vegetation of the Lower $\mathrm{U}$ Minh is an important ecosystem as it contributes to preserrve the nature while providing many bebefits. It is also used as an excellent indicator for identifying early signs of ecosystem change in the entire area. In order for that, however, an effective method should be used to reevaluate the change occurred during the past years. Use of remote sensing is the most effective method that serves for this purpose which was also used in the present study. In order to identify the vegetation change over a 40 years of time since 1975, three Landsat (TM) satellite images (1975, 1995 and 2015) were taken to develop the base maps which were then compared to identify the vegetation change of the national park. Using the base maps, six different vegetation types were identified using unsupervised and supervised classifications to build vegetation classification map with an overall accuracy of $86.33 \%$ and a kappa coefficient of 0.81 . The results showed that multi-temporal Landsat images with the average resolution bear the ability to assess the vegetation coverage changes. Though the total extent of the National Park has not been changed during the study period, the extents of its vegetation types changed in different manners. The grass cover changed from 155.57 ha in 1975 to 643.24 in 2015 while extent of water changed from 315.24 ha to 194.92 ha during the same period. The extents of the grass cover and water were 884.95 and 697.60 ha respectively in 1995. The Melaleuca forest cover of different ages was also changed in significant manner during the study period.
\end{abstract}

Keywords: Landsat, Remote sensing, the Lower U Minh National Park, Ca Mau

\section{Introduction}

Human life is now threatened due to climate change, largely by the loss of vegetation cover of the earth. Especially, the rainforests and related vegetation are in danger causing the potential loss of biodiversity. An estimated 7 million ha of forests are lost annually due to deforestation (FAO, 2016). Only 4 billion hectares of rainforests remain worldwide according to Global Forest Resources Assessment 2015 (Rainforest Action Network, 2017). Further, deforestation continues to be a major environmental issue which jeopardizes people's livelihoods, threatens the existence of species, and intensifies global warming. Thereby it continues to create severe social problems, sometimes leading to violent conflicts (Butler, \& Rhett, 2007). The total forest area in Vietnam is about 14,062 million hectares, which is about $40.84 \%$ of the total land area (Huong, 2015). According to the Ministry of Natural Resources and Environment, the primeval forests of Vietnam have seriously been reduced and only a very little is present today. Such areas mainly exist as the protection forests, conservation zones, and most of the natural forests which are the only examples of primeval forests (Tuan, 2009).

*Correspondence: upuls@sjp.ac.lk

Tel: +94714450339

ISSN 2235-9370 Print / ISSN 2235-9362 Online (C) University of Sri Jayewardenepura 
Wetlands provide significant economic, social and cultural benefits for the living being. They also provide primary products such as pasture, timber, fish, food, drinking water, fresh air and aesthetics and support recreational and tourist activities. Further, wetlands reduce the impacts of storm damage and flooding, maintain good water quality in rivers, recharge groundwater, store carbon, stabilise climatic conditions, protect biodiversity and control pest outbreaks (NSW, 2013).

$\mathrm{Ca}$ Mau province of Vietnam is one of the localities bears a large Melaleuca forest area which is of 35,000 ha. It is distributed mainly in the districts of U Minh, Tran Van Thoiand Thoi Binh in two typical soil groups, viz., alkaline soil and peat (Diem, 2013).With the large area of Melaleuca forest, it acts as a green wall against the wind blows from the West Sea and it is also considered as the green lung to keep the environment clean not only for Ca Mau city but also the whole Mekong Delta Region.

Due to this importance, UNESCO listed the Lower U Minh as one of the biosphere reserves of the world on $26^{\text {th }}$ May, 2009. The Lower U Minh National Park preserves spiritual and cultural values, acts as a historical monument of the region, provides opportunities for scientific research, sightseeing and tourism development. It also has the task of preserving genetic resources, re-creating the natural landscape (Hiep, 2005).

Since the establishment of National Park, the protection activities were uplifted to better conditions as it reduced frequent forest fires. However, fire eruption still occurs in the area mainly due to the existence of about 1,000 households with approximately about 5,000 people living adjacent to the Lower U Minh National Park as forest-dependents. Those families distributed along the east-west and south canal route forms the border surrounding the Lower U Minh (Board of the Lower U Minh National Park Management, 2015). These dwellers are farmers or hired laborers with very low income and therefore, they have continued to exploit the forest for non-timber products such as honey, fish, snakes, turtles and other animals. These activities influence the management for forest protection mainly due to eruption of fire due to the hot weather. Fires are more frequent in summer and it obviously makes the vegetation cover change in the park (Board of the Lower U Minh National Park Management, 2015).

Many studies were conducted on different aspects in the Lower U Minh National Park in the past. Its plant diversity and ecosystem management were studied by Tan (2005) and Hiep (2005) respectively while studies were conducted on fire eruption by Hiep (2005). Vegetation growth and peat layer were studied by Hoa et al., (2009), Quoi (2014) and Hong et al., (2015). However, a study on the temporal change of the vegetation structures had not been done in the past for the Lower U-Minh National Park. Availability of such information is vital for the park managers and for the annual reports which are currently prepared by various relevant agencies based on traditional mapping methods which are inaccurate as the scale is not considered. Further, the information generated by a proper mapping study using remote sensing and GIS activities would help the Management Board of the Lower U Minh National Park to understand the forest resources change through different stages. This will also act as a scientific database to help the management to conserve the National Park. Therefore the present study was conducted in the Lower U Minh National Park with the objectives of identifying the present vegetation distribution and mapping the vegetation cover change over the years of 1975, 1995 and 2015using remote sensing and GIS techniques.

Remote sensing and GIS techniques have been widely used in the past by many researchers to identify the vegetation change (Billingsley, 1984; Xie et al., 2008; Gandhi et al., 2015). Remote sensing helps the researchers to observe the history of the vegetations through the satellite images taken via various bands of the spectrum which can be enhanced by algorithms such as NDVI (Gandhi et al., 2015). GIS acts as a valuable tool to overlay the different images produced for different periods in the past to identify the changes. 


\section{Methodology}

\subsection{Characteristics the study area}

The Lower U Minh National Park belongs to U Minh and Tran Van Thoi districts of Ca Mau province in Vietnam. The total extent of the park is estimated to be about 8,476 ha. It is located between $9^{\circ} 12^{\prime} 30^{\prime \prime}$ to $9^{\circ} 17^{\prime} 41^{\prime \prime} \mathrm{N}$ and $104^{\circ} 54^{\prime} 11^{\prime \prime}$ to $104^{\circ} 59^{\prime} 29^{\prime \prime} \mathrm{E}$ (Figure 1). The average temperature in the area is $26.5^{\circ} \mathrm{C}$ and the average annual precipitation is $2,360 \mathrm{~mm}$. Its terrain is relatively flat and the average elevation varies from 1 to $1.5 \mathrm{~m}$ above sea level. The main soil types are peat and clay with alum sub-soils dominating in water logging areas.

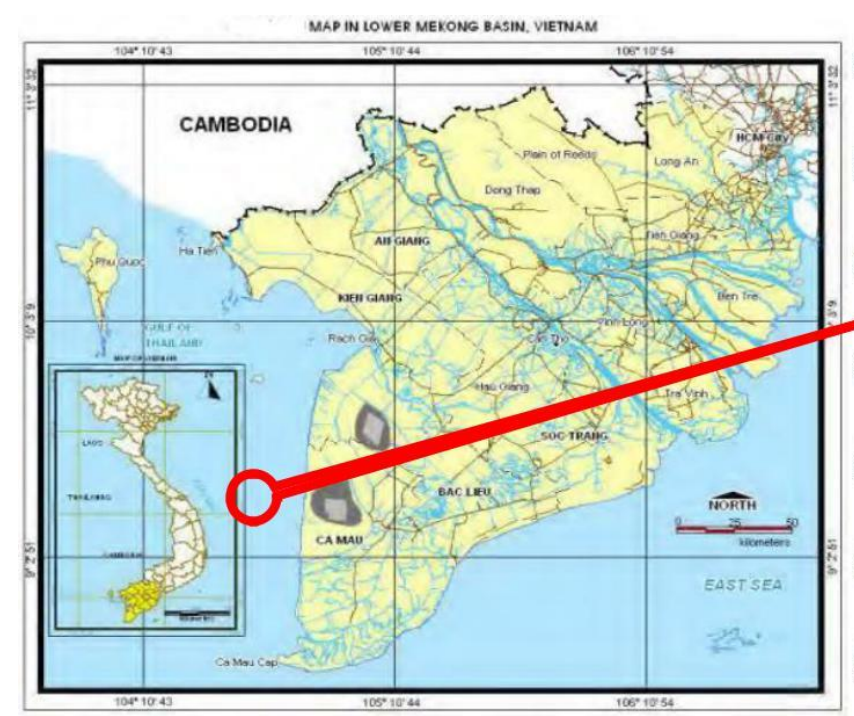

Figure 1: Location of the Lower $U$ Minh National Park (right) and Mekong Delta (left).

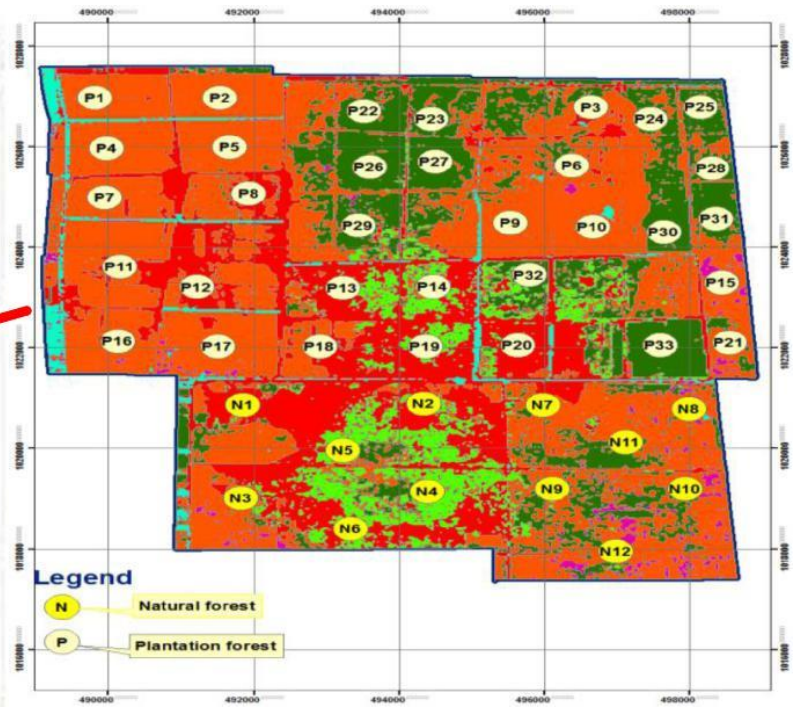

Figure 2: Layout of sample plots in the Lower U Minh National Park.

Due to the presence of dyke systems in the area, Lower U Minh National Park is not affected by the diurnal tidal of the West Sea. However, the area is flooded from 0.1 to $1 \mathrm{~m}$ during the rainy season for 5-6 months from June to November in each year. The amount of water in the forest can be adjusted, lowered or stored in each zone by regulating water through culverts. The vegetation of the Lower U Minh National Park dominates with Melaleucaca juputii belongs to Myrtaceae family.

\subsection{Data collection}

A total of 45 plots of $40 \times 40 \mathrm{~m}$ were used to study the vegetation types and species present in the National Park. Out of 45, 33 plots were laid in the plantation Melaleuca forest of various age classes and 12 plots were laid in natural Melaleuca forest area (Figure 2). Data on plant community composition, species abundance and relevant environmental characteristics were collected from those plots. In addition, ground cover percentage of the plants, plant/tree height and species diversity were also recorded. The species were identified at the field based on their morphological characteristics using the taxonomy guides of Ho (1993).

\subsection{Map building}

Three Landsat (TM) satellite images of different bands for 1975, 1995 and 2015 were downloaded from http://earthexplorer.usgs.gov and those were clipped to the study area basedon the respective land use maps. These multiband images were re-projected to UTM Zone 48 North, WGS-84 Datum. 
Thereafter, each image was exported to the ERDAS 2014 EX software and an image difference tool was used to detect the changes between 1975, 1995 and 2015 based on the Normalized Difference Vegetation Index (NDVI) as it is a useful method for determining plants depending on the distribution density. NDVI is functionally equivalent to simple band ratios of TM images and can be described as NDVI = (NIR band - RED band)/ (NIR band + RED band), where: NIR band $=$ spectral reflectance for band 4; RED band = spectral reflectance for band 3. Use of NDVI for this purpose has been well-justified by Gandhi et al. (2015).

Interpretation keys are then established followed by unsupervised classification which was first used to produce land cover classes for the study area using the ISODATA algorithm in ERDAS ER Mapper, which classifies the image into a pre-selected number of classes using an iterative calculation procedure to ensure maximum statistical separability based on the spectral data. This activity was able to identify 6 vegetation classes, viz., soil, water, grass, natural Melaleuca, plantation Melaleuca and regenerated Melaleuca with a 0.98 confidence interval.

Secondly a supervised classification was performed by using the Maximum Likelihood Classification tool. This algorithm uses the means and variances of the training data to estimate the probability that a pixel is a member of a class. The pixel is then placed in the class with the highest probability of membership. A confusion matrix was then built and image interpretation was completed based on the image selected according to the classification system. The resulting map is used to check and evaluate the accuracy by the field survey. In this study, random sampling method was used to evaluate classification accuracy. Image interpretation and data processing were conducted for the coverage maps of 1975, 1995 and 2015 by using ERDAS software. Ground verification activities were tested with the field data. ArcGIS 10.2 was finally used to overlay the maps of different years to compute the area of the object classes.

\section{Results}

\subsection{Survey results in the field}

The Lower U Minh National Park has been dominated by Melaleuca cajuputii trees with a grass community and vines. The Melaleuca forest is $88.64 \%$ of the total area of the National Park in 2015 and rest was comprised of bare soil, canals and grassland. The ground survey revealed that there are 104 plant species of natural plants belonging to 48 different families. Among them, grass and liana are the most dominant types. Although known as Melaleuca forest, there are 11 other tree species (Annona glabra, Alstonia spathuluta, llex thorelii, Trema orientalis, Acacia auriculiformis, Ficus microcarpa, F. pisocarpa, Morus alba, Eugenia cumini, Euodia lepta and Premna intergrifolia) found in the forest area. Apart from that, 4 shrub species, 4 herbaceous species, 38 grass species, 27 liana species, 14 aquatic weed species, and 6 fern species were recorded. The Meleluca area could be divided into two sub-zones as natural zone and plantation zone.

\subsection{Natural Melaleuca forest zone (grown on the peat land)}

Melaleuca trees growing naturally covered an extent of1, 844.46 ha in 2015 which is accounted for $21.76 \%$ of the total area. It was distributed in the southwest of the National Park (Figure 2). 59 flora species belonging to 34 families were identified in this forest, of which there were 9 species of woody plants, 4 shrubs, 4 herbaceous species, and 26 species of liana, 6 fern species and 10 species of grass. Apart from dominant Melaleuca tree species, some other plants such as Alstonia spathulata (Apocynaceae), llex cymosa (Aquifoliaceae), Euodia lepta (Rutaceae) and Syzygium cumini (Myrtaceae) were recorded in large numbers. Further, this forest type is characterized by an abundance of ferns, of which the two most common species are Stenochlaena palustris and Nephrolepis falcate. Shrub species 
are Glochidion littorale, Senna alata, Melastoma affine and Phyllanthus reticulatus. The Melaleuca density was low in the areas of the dominant grass and vines.

The highest number of Melaleuca trees was fallen into the DBH category of $>20 \mathrm{~cm}$ accounting to $31.19 \%$ with the average height of $14.78 \mathrm{~m}$. Trees of height $>20 \mathrm{~m}$ and DBH $>60 \mathrm{~cm}$ were also found, but few in numbers. The highest density of Melaleuca is 675 trees/ha while the lowest density is 318.75 trees/ha. The average density was 528.65 trees/ha and the depth of the peat layer was $1.2 \mathrm{~m}$.

\subsection{Plantation Melaleuca zone (grown on the clay soil)}

The Melaleuca plantation area is 5,668.87 ha in 2015, accounted for $66.88 \%$ of the total area of the National Park and this forest type usually appears at the outer edge of the peat (Figure 2). The regenerated Melaleuca after fires seared away on the layers of primitive peats with the total area of $1,653.97$ ha in the north and east of the national park which is accounted for $19.51 \%$ of the total extent.

The plantation Melaleuca is longed to six age classes, viz., 2, 4, 6, 8, 10, and 12 years. The average density of Melaleuca in this zone was 6,285.71 trees/ha with the average ground cover of $72.87 \%$. The average height was $11.74 \mathrm{~m}$ and the average DBH was $9.19 \mathrm{~cm}$. Phragmites vallatoria is the next common species with the average coverage of $16.1 \%$. The rest was fern and liana. The total number of species in the plantation zone was 38 of which 4 species are woody plants, 4 shrubs, 3 herbaceous species, 5 fern and 10 liana species. In addition, 12grass species were also found.

Grass species were usually present in wet areas along the canals and bogs where previously Melaleuca forests were burn down by humans. Besides the two dominant species of Eleocharis dulcis and Phragmitex sp., this habitat also had 38 other grass species. Vallatoria reeds grow along the main road from the front gateway of the National Park to the back gate and along the banks of canals on the dyke with the total reed area of approximately 5, 960, $166 \mathrm{~m}^{2}$. Height of reeds can reach up to $4 \mathrm{~m}$, forming single-species areas. Further, Eleocharis dulcis was found to be common along the routes distributed throughout the park along with reed grassland. The total area of E. dulcis grassland was estimated to be $1,190.000 \mathrm{~m}^{2}$. It was usually the dominant species, with density of about $95 \%$, and height about $30-70 \mathrm{~cm}$. Besides E.dulcis, other species such as Cyperus extentelatus, Cyperus exaltatus, Cyperus compactus, Eleocharis attropurea, Phragmites karka, Ludwigia adscendens, Ceratopteris thalictroides, Pistia stratiotes, Lemna minor and Nymphaea nouchali were also present.

The dominant species found in marsh were Nymphaea nouchali, Pistia stratiotes, Salvinia cucullata, ludwigiaadscendens and Hydrilla verticillata. These plants distribute in to dense floating arrays covering the entire water surface of the area forming dense-mat like vegetations. In addition, other plants species also appeared along with this species. Among them the common species were Eichhornia crassipes, Eleocharis dulcis, Ipomoea aquatic, Ludwigia adscendens, Leersia hexandra and Commelina diffusa. Apart from that, aquatic species such as Ceratopteris thalictroides; ludwigia adscendens; Eichhornia crassipes and monochoria vaginalis were found in the swamp. The total area of swamps was estimated to be $833,000 \mathrm{~m}^{2}$ in extent. Plant groups found in canals which were man-made were quite diverse. Vigna luteola, Commelina diffusa, Cyperus elatus and Ischaemum rugosum were found along the canal banks. Utricularia aurea, Hydrilla verticillata, Pistia stratiotes, Salvinia cucullata and Eichhornia crassipes were submerged or floating species in the canals. Many channel segments in the core area were heavily covered with dense floating carpet-like Eichhornia crassipes and Pistia stratiotes. Canal segments in the outer core areas often do not have this situation due to better water flow. The total canal area is 199 ha. 


\subsection{Map analysis}

The resultant NDVI values after classification of the study site into 6 vegetation classes are given in Table 1. NDVI values of negative or zero were placed where there was absolutely no presence of vegetation, e.g., bare soil, canals, flooded soil. Among them natural forest had the highest NDVI value of 0.368 to 0.722 (Table 1 ).

Table 1: NDVI index for the vegetation classes of the Lower U Minh National Park.

\begin{tabular}{lll}
\hline No & Vegetation Classes & NDVI \\
\hline 1 & Water & -0.951 to -0.129 \\
2 & Bare soil & -0.256 to 0.115 \\
3 & Grass & 0.194 to 0.282 \\
4 & Regenerated forest (<9 years) & 0.232 to 0.322 \\
5 & Plantation forest $(9-13$ years) & 0.312 to 0.387 \\
6 & Natural forest $(>13$ years) & 0.368 to 0.722 \\
\hline
\end{tabular}

The three vegetation cover maps built for the Lower U Minh National Park for 1975, 1995 and 2015 are given in Figure 3a-3d respectively. However, according to the results, map analysis using NDVI calculation is found to have some drawbacks. For instance, the NDVI values of grass and regenerated forest were approximately similar. Therefore, the interpretation of these two classes was initially not accurate. However, it was corrected by field observations with the help of a high quality GPS device. Further, an error matrix was used to accurately evaluate the results of the classification. The results of accurate assessment of vegetation classification based on the actual data set for the year 2015 are shown in Table 2.

According to Table 2, the accuracy of the classification of six vegetation layers by the supervised classification method ranged from $75 \%$ to $90 \%$. Most classes, however, had the accuracy interpretation over $80 \%$, except for grass and regenerated Melaleuca ( $<9$ years) which had the classification accuracy of $75 \%$ and $79 \%$, respectively. Table 2 also indicates that the overall classification accuracy is $86.33 \%$ and the overall kappa coefficient is 0.81 proving that the overall quality of image interpretation is high.

Table 2: Assess the accuracy of the Landsat image interpretation of vegetation cover classification in the Lower U Minh in 2015.

\begin{tabular}{llcc}
\hline No & Class Name & Producers accuracy & Users accuracy \\
\hline 1 & Unclassified & -- & -- \\
2 & Water & $93.33 \%$ & $87.50 \%$ \\
3 & Bare soil & $75.00 \%$ & $90.00 \%$ \\
4 & Grass & $75.00 \%$ & $75.00 \%$ \\
5 & Regenerated forest (<9 years) & $82.35 \%$ & $79.25 \%$ \\
6 & Plantation forest (9-13 years) & $90.35 \%$ & $89.57 \%$ \\
7 & Natural forest (>13 years) & $92.68 \%$ & $82.61 \%$ \\
\hline
\end{tabular}

Overall Classification Accuracy $=86.33 \%$

Overall Kappa Statistics $=0.8078$

Final results of the image classification of the National Park for 2015 are given in Figure 3d. The status of vegetation cover area of the study area in the period of 1975-2015 using satellite imagery is illustrated in Figure. 4. The area of natural Melaleuca (>13 years) decreased in 1995 compared to 1975 again increase in 2015, which is however, less than that of 1975. Plantation grown Melaleuca in the age 
of 9-13 show an increase which became the highest in 2015. The area of regenerated Melaleuca ( $<9$ years) increased in 1995 compared to 1975, again decreased in 2015.

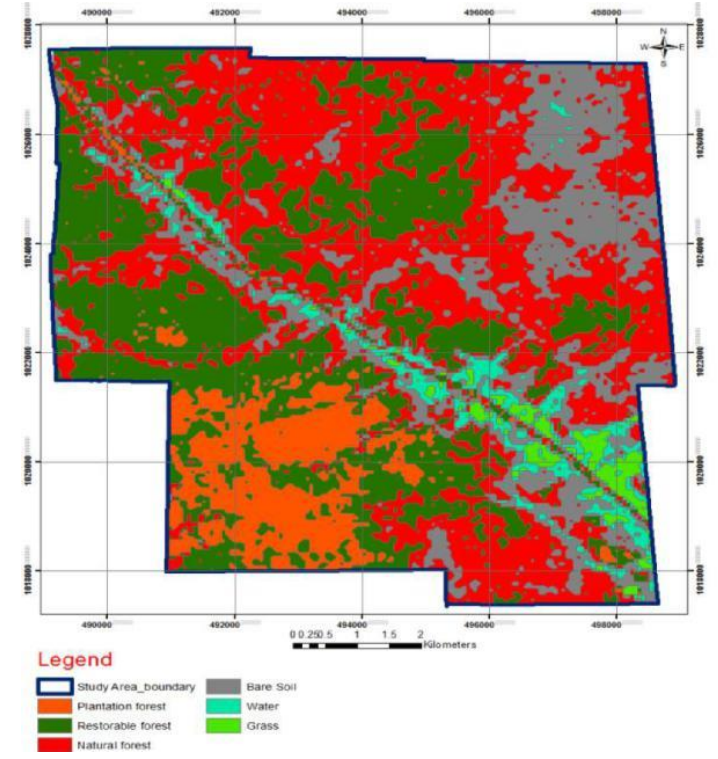

Figure 3a: The vegetation cover map of the Lower $\mathrm{U}$ Minh in 1975 by unsupervised classification.

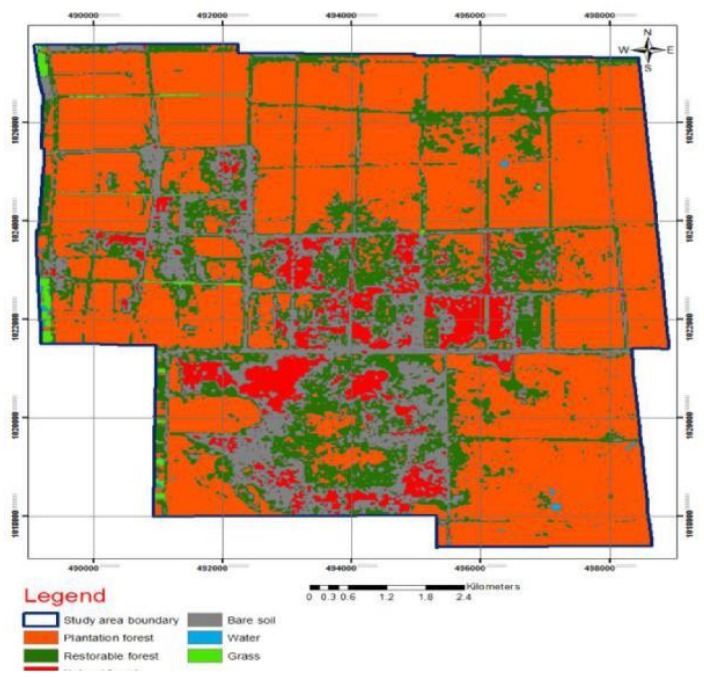

Figure 3c: The vegetation cover map of the Lower $\mathrm{U}$ Minh in 2015 by unsupervised classification.

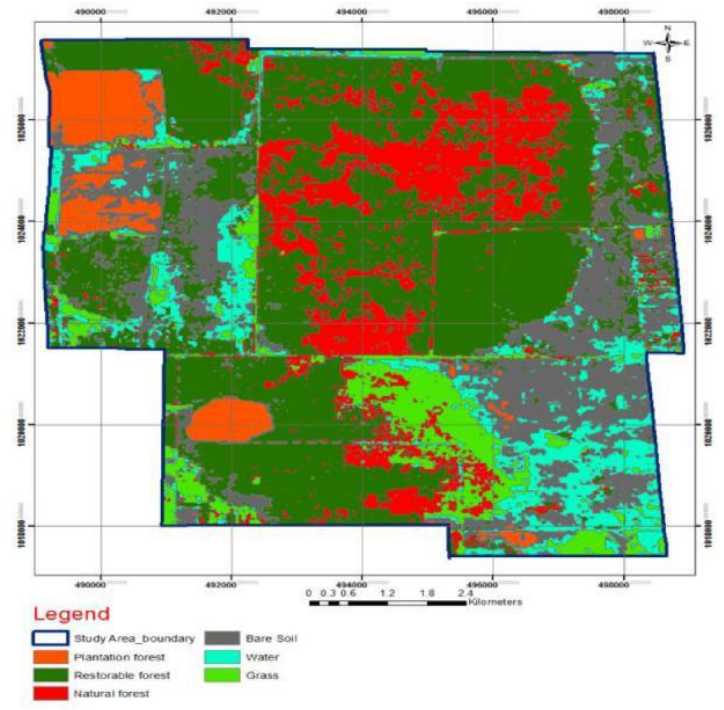

Figure 3b: The vegetation cover map of the Lower $U$ Minh in 1995 by unsupervised classification.

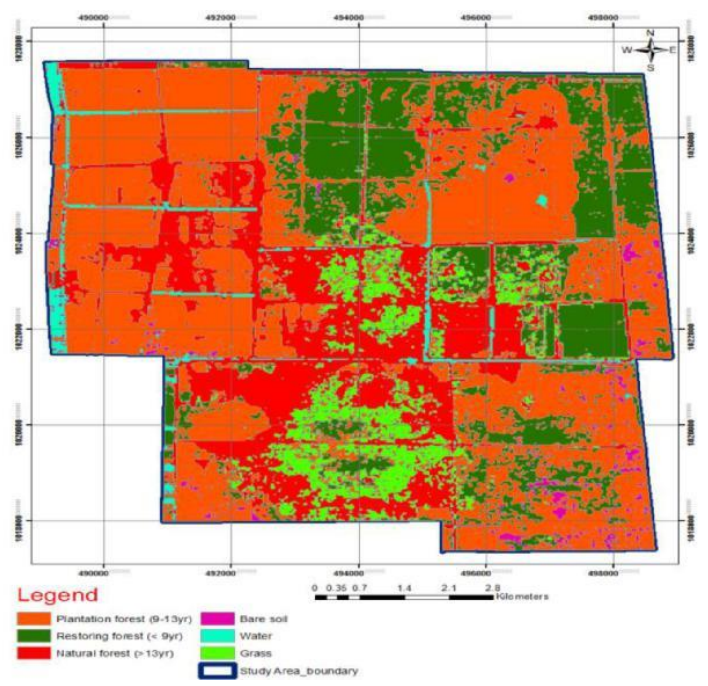

Figure 3d: The vegetation cover map of the Lower $U$ Minh in 2015 by supervised classification. 


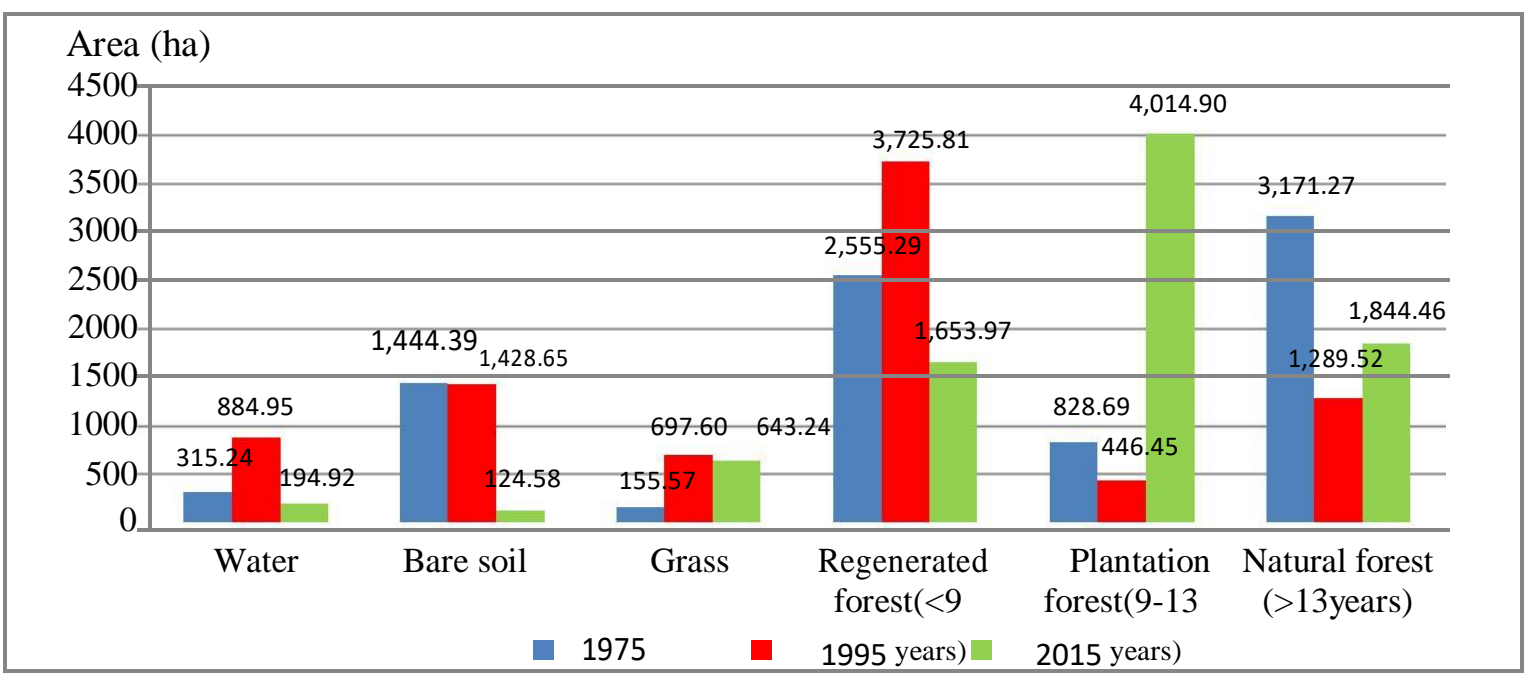

Figure 4: The vegetation cover area of the study area, 1975-2015.

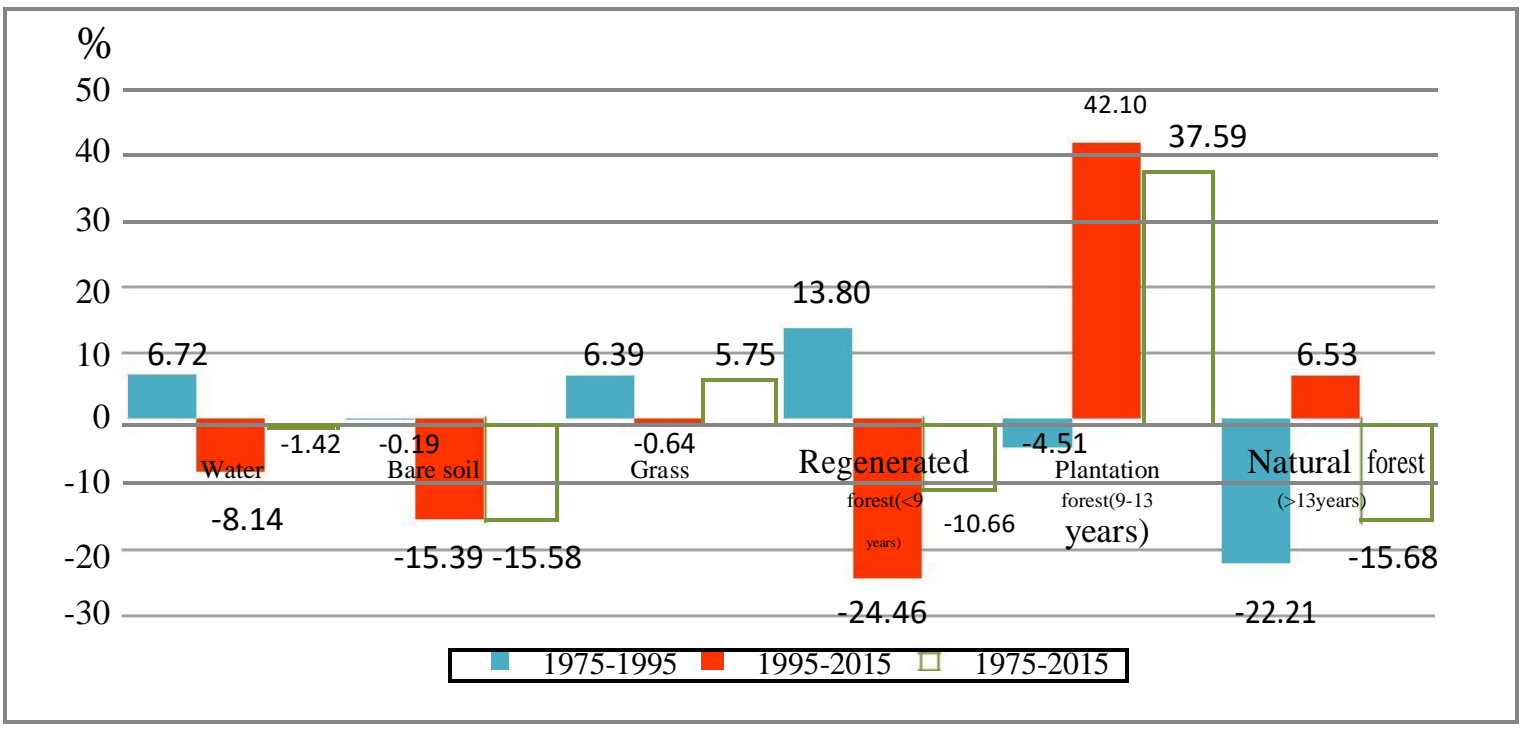

Figure 5: The changes percentage of vegetation area in the National Park, 1975-2015.

Change of the vegetation cover classes in the National Park is high during the study period (Figure. 5). From 1975 to 1995, the area of plantation Melaleuca (9-13 years) and natural Melaleuca (>13 years) decreased by $4.51 \%$ and $22.21 \%$ respectively from 1975 to 1995 . The reason for this could be the frequent forest fires occurred in that period. Moreover, the law enforcement was not strict during the same period and therefore many local people exploited Melaleuca forest for wood and firewood. After the fires, park management took actions to replant Melaleuca forest on burned forest land and thereby it regenerated together with weeds. Therefore, the area of regenerated Melaleuca forest ( $<9$ years) increased to $13.8 \%$. 


\section{Discussion}

Remote sensing based image analysis is especially appropriate over the traditional methods such as field surveys, literature reviews, map interpretation and collateral and ancillary data analysis for reconnaissance mapping and information monitoring for different types of wetlands spreading over large geographic areas (Langley, 2001; Nordberg, 2003). Successful use of remote sensing for detailed interpretation in wetland studies depends mainly on the spatial resolution of images. The present study also proved that remote sensing and GIS techniques is an optimal solution to the current forest cover mapping as it allowed a better comparison of vegetation change over the selected period of time.

Landsat image information extraction was carried out using unsupervised and supervised classification in this study to produce vegetation cover classes. Maximum likelihood classification (MLC) showed better results when compared with unsupervised classification for distinguishing vegetation classes. Supervised classification is depending on the user definition for training areas, aerial photography, and field verification which all were proven to be useful for the selection of vegetation classes. The six vegetation class-output map built by supervised classification using Landsat TM image analysis for 2015, showed high accuracy with the analysis of aerial photography for the same year. However, there was a problem in separating vegetation classes larger than the pixel size $(30 \mathrm{~m} \times 30 \mathrm{~m})$, such as waterlogged soil and water class; grass and Melaleuca, especially in selecting a training area because of the difficulty of distinguishing between classes producing similar colors of the reflection. This could lead them being coded with the same color in the image.

Landsat images have been applied in vegetation mapping mainly at regional scales. Since Landsat has a long history of dataset, it is very helpful to map long-term vegetation cover and study the spatiotemporal vegetation changes. For example, nearly 20-year continuous Landsat TM/ETM+ image datasets (19 images) covering western Oregon were used to detect and characterize continuous changes in early forest succession (Schroeder, 2006). Landsat TM images, striding a long period of time from 1986 to 2002, were used to conduct quantitative analyses of wetland landscape patterns and their dynamic changes in the estuary of the Minjiang River (Zheng, 2006). Because of the different characteristics of spectral sensors (i.e. TM and ETM+) in the Landsat image series, it is necessary to correct the spectral reflectance between images acquired by those sensors. This is especially necessary in long-term vegetation cover monitoring research where both Landsat TM and ETM+ images are used (Yichun,2008). Due to the limitation of spatial resolution, Landsat products are usually used to map vegetation at community level (Domaç, 2006).

A few studies were conducted in Vietnam on the application of remote sensing and GIS techniques for the establishment of forest cover maps though the extent of remote sensing information was limited. The use of NDVI was recognized by those studies as a useful method to detect the vegetation differences. Thom (2014) successfully used NDVI method for satellite image classification for Thanh Mai commune of Cho MoiBac Can (Thom, 2014). The same method was successful for the present study which was proven by the kappa index of 0.81. Thanh (2013) also used the same method of classification with 2006 Landsat image data for establishing 7 different vegetation classes which had the kappa index of 0.7 which was lower than the kappa index of the present study (Thanh, 2013). Six vegetation classes for Tram Chim National Park of Dong Thap for the period of 1995 to 2013was done by supervised classification with SPOT 1995 and ASTOR 2013 and the resultant kappa coefficient was 0.8 (Tien, 2014). These results showed that the interpretation of LANDSAT images provides similar results to that of SPOT and ASTER images. 


\section{Conclusions}

Multi-temporal Landsat images with a 30m spatial resolution can be used for the assessment of vegetation coverage changes with guaranteed results.

The present study showed that there were 104 species of natural plants, belonging to 48 different plant families: 11 species of woody trees, 4 shrub species, 4 herbaceous species, 38 grass species, 27 liana species, 14 aquatic species and 6 fern species. Natural Melaleuca forest covered an area of 1,844.46 ha in 2015 which was accounted for $21.76 \%$ of the total area. The rest was planted on clay, distributed over the remaining area $(66.88 \%$ ) and the bare soil, canals land, grass land were $11.36 \%$.

The information elaborated in the present study can effectively be used to identify the areas of the Lower U-Minh National Park to be used for obtaining benefits and the areas that should be conserved. For example, the details of the different age classes of planted $M$. cajuputi are helpful to estimate the tangible benefits in accordance with the policies of the National Park use. Further the details of the other areas can be used for the conservation management activities.

\section{References}

Billingsley, F.C. 1984. Remote sensing for monitoring vegetations: an emphasis on satellites. In The role of vegetations in the global carbon cycle: measurement by remote sensing (G.M. Woodwell), John Wiley and Sons. Board of the U Minh National Park Management. 2015. The deep interview results of status of forest management and protection.

Butler, Rhett A. 2007. Primary rainforest richer in species than plantations, secondary forests: (https://news.mongabay.com/2007/07/forest-disturbance-reduces-biodiversity-in-the-amazonrainforest). Accessed on $02^{\text {nd }}$ July 2007.

Diem, P. 2013. Discovery of the Lower U Minh. ( http://www.camau.gov.vn/wps/portal/!ut /p/a0/04_Sj9CPyk) Accessed on 01 ${ }^{\text {st }}$ December 2013.

Domaç, A., Süzen, M.L. 2006. Integration of environmental variables with satellite images in regional scale vegetation classification. International Journal of Remote Sensing, 27: 1329-1350.

FAO. 2016. Global forest resources assessment 2015: How are the world's forests changing? Food and Agricultural Organisation of the United Nations, Rome.

Gandhi, M., Parthiban, S., Thummalu, N., Christy, A. 2015. NDVI: vegetation change detection using remote sensing and GIS: a case study of Vellore District. Procedia Computer Science, 57: 11991210.

Geist, H.J.,Lambin, E.F. 2002. Proximate causes and underlying driving forces of tropical deforestation. American Institute of Biological Sciences, 52(2): 143-150.

Ho P.H. 1993. An illustrated flora of Vietnam. The South Vietnamese Ministry of Education, Vietnam.

Hong, T.T., Long, N.B., Ni, D.V., Be, N.V. 2015. Peat thickness affecting growth indexes of the Melaleuca forest in the U Minh Ha National Part, Ca Mau province. Journal of Science, Can Tho University,40: 92-100.

Huong, D. 2016. The average coverage percentageof Vietnamese Forest (http://baochinhphu.vn/Hoatdong-dia-phuong/Do-che-phu-rung-Viet-Nam-dat-4084/283007.vgp). Accessed on $1^{\text {st }}$ August 2016.

Keenan, R., Reams, G., Freitas, J., Lindquist, E., Achard, F., Grainger, A., 2015. Dynamics of global forest area: Results from the 2015 global forest resources assessment. Forest Ecology Management, 352: 9-20.

Langley, S.K.,Cheshire, H.M.,Humes, K.S., 2001. A comparison of single date and multi-temporal satellite image classifications in a semi-arid grassland. Journal of Arid Environment, 9: 401-411. 
NSW, 2013. Why are wetlands important?

(http://www.environment.nsw.gov.au/wetlands/WhyAreWetlandsImportant.htm).Accessedon28 ${ }^{\text {th }}$ Novemb er 2017.

Nordberg, M.L.,Evertson, J., 2003. Vegetation index differencing and linear regression for change detection in a Swedish mountain range using Landsat TM and ETM+ imagery.Land Degradation \& Development, 16: 139-149.

Quoi, L.P. 2014. Peatlandassesment in The U Minh Ha National Park, Ca Mau province. Institute for environment and natural resource national university at Ho Chi Minh City.SNV- Netherlands Development Organisation REDD+ Programme. Ha Noi, Vietnam.

Rainforest Action Network, 2017. How many trees are cut down every year? (https://www.ran.org/how_many_trees_are_cut_down_every_year)Accessed on 06 ${ }^{\text {th }}$ March, 2017.

Schroeder, T.A.,Canty, M.J,Yang, Z. 2006. Radiometric correction of multi-temporal Landsat data for characterization of early successional forest patterns in western Oregon.Remote of Sensing Environment, 103:16-26.

Tan, D.T. 2005. Ca Mau flooded forest ecosystem. (http://vafs.gov.vn/vn/2005/07/he-thuc-vat-rung-ngapca-mau/). Accessed on $06^{\text {th }}$ July 2005.

Thanh, H.X. 2013. Establishment of vegetation map based on remote sensing image analysis, MSc Thesis. Water Resources University, Vietnam.

The Nature Conservancy. 2015. Facts About Rainforests: (

https://www.nature.org/ourinitiatives/.../rainforests/rainforests-facts.xml).Accessed on $19^{\text {th }}$ October 2015.

Thom, T.T., Que, P.T. 2014. Using remote sensing data and GIS to establishment of forest status map at the scale of 1:10.000. Journal of Forest Science \& Technology, 4: 161-168.

Tien, P.D. Thang, T.N. Duong, L.V, 2014. Mapping change vegetation cover at Tram Chim National Park, Dong Thap, 1995-2013. Proceedings of the nationwide GIS application workshop in Vietnam, 2: 615-623.

Tuan, H.C. 2009. Overview of forest protection in Vietnam and solutions of forest protection. Forest protection department-Ministry of Agricultural and rural development:

(http://www.kiemlam.org.vn/Desktop.aspx/List/So12/tong_quan_ve_bao_ve_rung_viet_namva_n hung_giai_phap_bao_ve_rung/). Accessed on $06^{\text {th }}$ January 2009.

Xie, Y., Sha, Z., Yu, M. 2008. Remote sensing imagery in vegetation mapping: a review. Journal of Plant Ecology, 1: 9-23.

Yichun, X., Zongyao, S., Mei, Y., 2008. Remote sensing imagery in vegetation mapping: a review. Journal of Plant Ecology, 1: 9-23.

Zheng, C.H.,Zeng, C.S.,Chen, Z.Q.2006. A study on the changes of landscape pattern of Estuary wetlands of the Minjiang River,Wetland Science,4: 29-35. 